\title{
Erratum: Mina, R.; et al. Minimal Residual Disease in Multiple Myeloma: State of the Art and Future Perspectives. J. Clin. Med. 2020, 9, 2142
}

\author{
Roberto Mina ${ }^{*}+\mathbb{\infty}$, Stefania Oliva ${ }^{\dagger}$ and Mario Boccadoro \\ Myeloma Unit, Division of Hematology, University of Torino, Azienda Ospedaliero-Universitaria Città della \\ Salute e della Scienza di Torino, via Genova 3, 10126 Torino, Italy; stefania.olivamolinet@gmail.com (S.O.); \\ mario.boccadoro@unito.it (M.B.) \\ * Correspondence: roberto.mina.rm@gmail.com; Tel.: +39-011-633-4301 \\ + These authors equally contributed to this manuscript and share first authorship.
}

Received: 31 July 2020; Accepted: 7 August 2020; Published: 13 August 2020

The authors sincerely apologize for the inaccuracies made during the revision that a product line has been associated with the wrong company. They wish to make the following corrections to the previous paper [1].

On page 2 of the published paper (Section 2.1. MRD in the Bone Marrow), the authors would like to replace the inaccurate sentence:

Other non-commercial NGS technologies are under investigation: the LymphoTrack ${ }^{\circledR}$ assay (Invitrogen, US-MA) has been recently validated in a phase II study [2], and the EuroClonality-NGS Consortium (an international group of 21 academic laboratories experienced in NGS) has recently validated IG/TR NGS assays and a bioinformatic tool for an academic study on MRD [3].

With the following sentence:

Other non-commercial NGS technologies are under investigation: the LymphoTrack ${ }^{\circledR}$ assay (Invivoscribe, Inc., US-CA) has been recently used to establish IGH chain clonality for NGS characterization of B-Cell and plasma cell neoplasms [4]. Martinez-Lopez et al. validated an "in-house deep-sequencing" method in a phase II study by using standardized primers developed by the Biomed-2 Concerted Action, in order to amplify all IGH or IGK sequences [2]. Furthermore, the EuroClonality-NGS Consortium (an international group of 21 academic laboratories experienced in NGS) has recently validated IG/TR NGS assays and a bioinformatic tool for an academic study on MRD [3].

The published version will be updated online on the article webpage, with a reference to this Erratum.

Conflicts of Interest: R.M. has received honoraria from Amgen, Celgene, Takeda and Janssen; has served on the advisory boards for Janssen. S.O. has received honoraria from Amgen, Celgene and Janssen and has served on the advisory boards for Adaptive Biotechnologies, Janssen, Amgen and Takeda. M.B. has received honoraria from Sanofi, Celgene, Amgen, Janssen, Novartis, AbbVie and Bristol-Myers Squibb and has received research funding from Celgene, Janssen, Amgen, Bristol-Myers Squibb, Mundipharma, Novartis and Sanofi.

\section{References}

1. Mina, R.; Oliva, S.; Boccadoro, M. Minimal Residual Disease in Multiple Myeloma: State of the Art and Future Perspectives. J. Clin. Med. 2020, 9, 2142. [CrossRef] [PubMed]

2. Martinez-Lopez, J.; Sanchez-Vega, B.; Barrio, S.; Cuenca, I.; Ruiz-Heredia, Y.; Alonso, R.; Rapado, I.; Marin, C.; Cedena, M.T.; Paiva, B.; et al. Analytical and clinical validation of a novel in-house deep-sequencing method for minimal residual disease monitoring in a phase II trial for multiple myeloma. Leukemia 2017, 31, 1446-1449. [CrossRef] [PubMed] 
3. Brüggemann, M.; Kotrová, M.; Knecht, H.; Bartram, J.; Boudjogrha, M.; Bystry, V.; Fazio, G.; Froňková, E.; Giraud, M.; Grioni, A.; et al. Standardized next-generation sequencing of immunoglobulin and T-cell receptor gene recombinations for MRD marker identification in acute lymphoblastic leukaemia; a EuroClonality-NGS validation study. Leukemia 2019, 33, 2241-2253. [CrossRef] [PubMed]

4. Arcila, M.E.; Yu, W.; Syed, M.; Kim, H.; Maciag, L.; Yao, J.J.; Ho, C.; Petrova, K.; Moung, C.; Salazar, P.; et al. Establishment of Immunoglobulin Heavy (IGH) Chain Clonality Testing by Next-Generation Sequencing for Routine Characterization of B-Cell and Plasma Cell Neoplasms. J. Mol. Diagn. 2019, 21, 330-342. [CrossRef] [PubMed]

(C) 2020 by the authors. Licensee MDPI, Basel, Switzerland. This article is an open access article distributed under the terms and conditions of the Creative Commons Attribution (CC BY) license (http://creativecommons.org/licenses/by/4.0/). 